\title{
Concept of Galactogogue (Mudirr-i-Laban) in view of Unani Medicine
}

\author{
Sofia Naushin \\ Central Council of Research in Unani Medicine, Ministry of Ayush, Govt. of India, New Delhi \\ Available online at: www.isroset.org \\ Received: 05/Apr/2019, Accepted: 16/Apr/2019, Online: 30/Apr/2019
}

\begin{abstract}
The WHO recommends exclusive breastfeeding for infants up to six months as the normal infant feeding method and considered "gold standard" of infant nutrition. In the first few days of neonatal life in exclusively breastfed infants, excessive weight loss and late birth weight catch-up are emerging problems. Lactation failure due to poor breastfeeding technique and insufficient breast milk production can cause several medical conditions in infants such as dehydration, hypernatremia, and hyperbilirubinemia. Synthetic drugs have significant adverse effects in both mother and infant. Mudirr-i-Laban (galactogogue) is the medications in Unani medicine that could help in increasing milk production to overcome the insufficient lactation without any adverse effect in mother and infant. Many herbs are used to increase breast milk production can easily and safely be added to the everyday diet. This review expands the concept of Mudirr-i-Laban (galatogogue) mentioned in Unani system of medicine and some common natural herbal galactogogue used in the management of Qilla al-Laban (oligogalactacea). Only few of them have been experimentally studied. Studies are needed to gives verification for the mechanism of action of these herbs as galactogogue.
\end{abstract}

Keywords: Qilla al-Laban, Mudir-e-laban, Unani medicine, Galactogogue

\section{INTRODUCTION}

Mother's breast milk is the best possible source of nutrition for babies. As stated by WHO, exclusive breastfeeding should be started within one hour after birth until a baby is six months old [1]. After parturition, the establishment of a mature milk supply is dependent upon the presence of mammary tissue, regular removal of milk from the mammary gland, and maternal hormones such as prolactin and oxytocin. Prolactin stimulates the mammary glands to initiate lactation. It is associated with numerous physiological processes in addition to lactation. Oxytocin is necessary for 'milk ejection reflex' or 'let-down' to occur. These two hormones must be present for lactation to become established. Neither hormone determines the amount of milk produced in a lactating breast; rather, this is a feedback mechanism depend upon the quantity of milk removed from the breast, and the frequency of milk removal [2].

In addition to the maternal hormonal balance, successful establishment of the milk supply relies on a proper breastfeeding technique such as good latch. Proper breastfeeding technique on the part of mother and baby ensures adequate milk removal, and is usually sufficient to maintain an ample supply of milk. Reportedly, due to perception of insufficient milk supply breastfeeding efforts are most often unsuccessful [3]. It is caused by an imbalance in maternal hormones, some deficiency in the mammary tissue, or most often, inadequate milk removal due to poor latch. If the problem of deficient milk supply remains after inadequate breastfeeding technique (such as poor latch) have been ruled out, galactagogue (Mudirr-i-Laban) substances can be helpful [4].

This paper is organized as follows, section I contains the Introduction to the oligogalactacea, section II contains reason for development of safe and effective herbal galactogogue for augmentation of breast milk, section III contains unani perspective on qilla al-laban (oligogalactacea), section IV explains in detail the different views of ancient physician regarding qilla allaban (oligogalactacea), section V contains list of some unani medicinal plants having galactogogue activity, section VI describes principles of treatment in unani medicine and the section VII presents the conclusion of the paper.

\section{Reason for development of safe and effective approaches for augmentation of breast milk}

Most common reasons given for discontinuing breastfeeding are low milk supply and for initiation, maintenance, and augmentation of maternal milk production; medications such as Mudirr-i-Laban (galactogogue) are needed [5]. Synthetic drugs such as metoclopramide, domperidone, chlorpromazine and sulpiride are most commonly used galactogogues; they show significant adverse effects in mothers like gastrointestinal disorders, dry mouth syndrome or hyposalivation, cardiac 
arrhythmia, lethargy, sedation, extra pyramidal symptoms such as hypertension, tremor, facial seborrhoea and hyperhidrosis and even sudden death. Symptoms in infants due to ingestion of milk from treated mothers are intestinal discomfort, lethargy and sedation. Dopamine antagonists, such as antiemetic metoclopramide and domperidone and antipsychotics sulpiride and chlorpromazine are mainly used among synthetic drugs to increase lactation. Synthetic hormonal analogs such as oxytocin, rBST, TRH and medroxyprogesterone are also used as synthetic galactogogues [6]. Due to the adverse side effects from the pharmaceutical galactagogues, people turned towards an alternative approach in overcoming the situation through the utilization of herbal products which are reported to be the safest galactagogues presently available. The use of natural products supposed to be capable of increasing milk production has a long history.

\section{Unani literature on Qilla al-Laban}

In classical Unani literature, insufficient lactation (oligogalactacea) is described as 'Qilla al-Laban'. The Unani physicians like Ibn Sīnā, Zakariyya Rāzì, Rabban Tabarī , Akbar Arzānī have mentioned several herbs used as a Mudirr-i-Laban (galatogogue). Qilla al-Laban is due to Ghalaba-i-Akhlat (excess of humour) which altered the quality of the Madda khoon (blood humour) and body is not able to produce milk. Quality of milk can help in diagnosing the type of Ghalaba-i-Akhlat involved in Qilla al-laban. If colour of milk will be yellowish and consistency of milk will be thinner than the normal then Qilla al-laban is due to ghalba-i-Safrä' (bile). If consistency of milk will be thick then it is due to ghalba-i-balgham (phlegm) [7,8]. If milk becomes more viscid, turbid and less in quantity then it is due to ghalba-i-Sawdā'. Other causes are Zof-i quwwat-i-jaziba (weakness in attractive power) of breast, Qillat-e-khoon (anaemia), Nafās (puerperal blood losss), Kathrat-iHayd (menorrhagia), [9] Ghiza ki kami (poor diet) and Awarizat-e- Nafsāniyya (psychological complications), which makes the quality of blood poor and body cannot produce milk [10].

\section{Different Views of Ancient Physician}

$\checkmark \quad$ Ibn Sina described Qilla al-Laban' is caused by altered quality of blood where the blood element (madda khoon) is decreased, or abnormal temperament (S $u^{\prime}$-i-Mizäj) or abnormal humours (Ghayr TTabì ‘ khilt) [7].

$\checkmark$ Zakariyya Rāzì mentioned the causes of Qilla al-Laban' are alteration in kaifyat-e-dam (quality of blood), which can be due Qilla al dam (anaemia) or dominance of Khilt-i-Balgham (phlegm). He has mentioned in his book Al-Hawi that drugs which has Mudirr-i-Hayd (emmenogogue) property will also have Mudirr-i-Laban (milk secreting) property [11].

$\checkmark$ According to Rabban Tabarī and Akbar Arzānī, muwallid-i-mani (ovulation inducing drugs) also possess the muwallid-i-laban (milk producing) property $[9,12]$.

$\checkmark$ Akbar Arzānī described Qilla al-Laban' is caused by zof e quwwat-i-jaziba (weakness in attractive power) of breast, qillat e khoon (anemia), Nafās (puerperal blood loss), Kathrat-i-Hayḍ (menorrhagia) [9].

$\checkmark \quad$ In Unani classical texts the herbs mentioned under the heading as a Mudirr-i-Laban or Muwallid-i-Laban possess the properties like muqaww-e-bah (aphrodisiac), [13] musammin-e-badan (body strengthen) [14] which also helps in adequate milk production because of their nutritive properties.

$\checkmark \quad$ Ismail Jurjānī mentioned that Qilla al-Laban' caused by Su'-i-Mizäj-i-badan (abnormal temperament of body) or pistān (breast)[15]. In Unani classical texts various herbs mentioned as Mudirr-i-Laban or muwallid-i-laban might be a useful tool in the treatment of insufficient milk production in mothers.

$\checkmark$ Ajmal Khān mentioned that mother is affected psychologically and emotionally by Qilla al-Laban' as the baby is unsatisfied by the feeds, cries frequently, malnourished, and fall sick frequently [16].

$\checkmark$ Oxytocin is necessary for the milk ejection reflex, or let down to occur [17]. Mudirr-i-Hayd drugs possess oxytocic property which cause contraction of the myoepithelial cells and improves secretion [18].

UNANI MEDICINAL PLANTS HAVING GALACTOGOGUE ACTIVITY

\begin{tabular}{|r|l|l|l|l|}
\hline \multicolumn{2}{|l}{ S.No. } & Unani Name & \multicolumn{3}{l|}{ Part Used References } \\
\hline 1. & Zīra Safed & Cuminum cyminum Linn. & Seeds & {$[19]$} \\
\hline 2. & Zīra Siyāh & Carum cavri & Seeds & {$[19]$} \\
\hline 3. & Satāvar & Asparagus recemosus Wild. & Root & {$[20]$} \\
\hline 4. & Bādiyān & Foeniculum vulgare Linn. & Seeds & {$[20,21]$} \\
\hline 5. & Asgand & $\begin{array}{l}\text { Withania somnifera } \\
\text { Dunal }\end{array}$ & Root & {$[14,21]$} \\
\hline 6. & Ajwā'in & Trachyspermum ammi & Seeds & {$[22]$} \\
\hline 7. & Mūṣlī safaid & Chlorophytum arundinacecum Linn. & Root & {$[22]$} \\
\hline 8. & Mūṣlī Siyāh & Curculigo orchioides Gaertn. & Root & {$[22]$} \\
\hline 9. & Alsī & Linum usitatissimum Linn. & Seeds & {$[21]$} \\
\hline
\end{tabular}




\begin{tabular}{|c|c|c|c|c|}
\hline 10 & Hulba & Trigonella-foenum-graecum Linn. & Seeds & {$[22]$} \\
\hline 11 & Aspand & Peganum hermala Linn. & Seeds & [22] \\
\hline 12 & Panbadana & Gossypium herbaceum Linn & Seeds & [19] \\
\hline 13 & Maghz-i chilghoza & Pinus gerardiana & Fruit & [21] \\
\hline 14 & Tukhm-i Tarbūz & Citrullus vulgaris Linn. & Seed & {$[21]$} \\
\hline 15 & Khurmā (Tamr) & Phoenix dactylifera Linn. & Fruit & [14] \\
\hline 16 & Habba-al-Sawdā' & Nigella sativa Linn. & Seeds & [22] \\
\hline 17 & Maghz-i tukhm-i kadū & Lagenaria siceraria Standly & Seed & [21] \\
\hline 18 & Ash-i-Jaw & Hordeum vulgare Linn. & Leaves & {$[22]$} \\
\hline 19 & Akhrot & Juglans regia Linn. & Fruit & [22] \\
\hline 20 & Bādām & Prunus amygdalus Bail. & Fruit & {$[21]$} \\
\hline 21 & Gul-i Mahuwa & Madhuca longifolia Linn. & Fruit & {$[21]$} \\
\hline 22 & Sa'lab misri & Orchis latifolia Linn. & Root & {$[22]$} \\
\hline 23 & Hulhul & Ipomoea digitata Linn. & Root & {$[22]$} \\
\hline 24 & Halyūn & Lepidium sativum Linn. & Seeds & [23] \\
\hline 25 & Shiqāqul misri & Pastinaca sativa Linn. & Root & {$[19,20]$} \\
\hline 26 & Kunjad & Sesamum indicum Linn. & Seeds & {$[22]$} \\
\hline 27 & Maghz-i pista & Pistacia vera Linn. & Fruit & {$[22]$} \\
\hline 28 & Tūdrī Surkh & Cheiranthus cheiri & Seeds & {$[20,21]$} \\
\hline 29 & Tūdrī zard & Lepidium iberis & Seeds & {$[20,21]$} \\
\hline 30 & Anīsūn & Pimpinella anisum Linn. & Seeds & {$[22]$} \\
\hline 31 & Anjīr (Tīn) & Ficus carica Linn. & Fruit & {$[22]$} \\
\hline 32 & Sambhaloo & Vitex negundo Linn. & Seeds & {$[20]$} \\
\hline 33 & Tukhm-i Gazar & Daucus carota Linn. & Seeds & {$[21]$} \\
\hline 34 & Maghz-i tukhm-i kharpaza & Cucumis melo Linn. & Seed & {$[21]$} \\
\hline 38 & Nagar motha & Cyperus rotundus Linn. & Root & {$[20]$} \\
\hline 36 & Otangan & Blepharis edulis Pers. & Seeds & [23] \\
\hline 37 & Boazidan & Pyrethrum indicum & Root & {$[22]$} \\
\hline 38 & Tukhm-i gandanā & Allium ascalonicum & Seeds & [21] \\
\hline 39 & Singhada & Trapa bispinosa & Fruit & {$[22]$} \\
\hline 40 & Maghz-i Narjīl & Cocos nucifera & Fruit & [22] \\
\hline 41 & Unnāb & Ziziphus sativa Gaertn & Fruit & {$[20]$} \\
\hline
\end{tabular}

\section{UṢU $\bar{U} L I$ 'ILĀJ (PRINCIPLES OF TREATMENT)}

* 'Iläj bi’l-Tadbīr (Physiotherapy):

$\checkmark \quad$ In kasrate dam (polycthemia), fașd (venesection) and Hijäma (cupping) are done and fasad khoon (impurity of blood) is to be rectified [6].

$\checkmark$ Gentle dry cupping (Hijäma) also given beneath the breasts [24].

* 'Iläj bi'l-Ghidhā' (Dietotherapy):

$\checkmark$ Azam Khan mentioned that balance and nutritive diet is enough for improvement in Qilla al-laban and drugs are not needed [8].

$\checkmark \quad$ If there is any indication of cold temperament, obstruction or inadequate absorption, diet should be light (lateef) and slight hot in temperament [24].

$\checkmark$ Akbar Arzāni stated diet such as milk, egg yolk, and chicken meat is used to increase blood production in anaemia that eventually leads to increased milk production [10].

$\checkmark \quad$ Ibn Siña stated diet such as barley soup, mixed with seeds of fennel (tukhm-i bādiyānn) root of fennel (bekh-i bādiyān), seed of tukhm-i shibit, black cumin (kalonjī) is beneficial in malnutrition. [7, 24] The diet which is hot and moist such as milk, rice, chicken or honey with milk, faluda, halwa of egg yolk are also useful [7,11]. Due to malnutrition and dryness, if the milk production is not sufficient, animal milk is useful [15].

* 'Iläj bi'l-Dawā' (Pharmacotherapy):

$\checkmark \quad$ Ibn Siñ described that drug with first degree mizāj (temperament) is useful in Qilla al-Laban' [7].

$\checkmark \quad$ Mudirr-i-Laban drugs are useful such as hulba (fenugreek), seeds of turnip (tukhm-i shalgam), ghee, green gram, etc. [11].

$\checkmark \quad$ In dominance of ghalba-i-sauda (black bile), musakkhin (analgesic) and muratib (moist) drugs such as harīra anjīr (soup of fig), jaw, gandum (wheat) with roghan-i badam (almond oil) are beneficial [8]. 
$\checkmark \quad$ In dominance of ghalba-i-balgham (phlegm), drugs with hot temperament such as bādiyān, shibit, and karafs are used. Soup of ārd-i Gandum (wheat flour) with hulba, bādiyān and asl is advised and after that habb-i mushil is given [8].

$\checkmark \quad$ muwallid-i-mani drugs such as tüdrī safed, tukhm-i kashkhash safed and the nutritious diet which is här and tar increases the production of milk $[11,15,17]$.

\section{CONCLUSION}

In the emerging circumstances the health policies in India and across the globe have been emphasizing on reproductive and child healthcare and also exploring the possibility of introducing traditional systems of medicine such as unani, integrating with conventional medicine to achieve better healthcare. Further integration of unani and other Traditional system of medicine possibly offer safe and effective management of child health. Owing to the importance of breast milk and breast feeding as recognized by unani thousands of years ago and also endorsed by modern science, need is felt to promote these practices which are pivotal for physical, psychological and emotional development of child besides considerable immunological support. The potential leads form unani texts may be taken forward for further development of safe and effective and user friendly dosage forms through systematic pre-clinical and clinical studies.

Many single herbs such as Hulba (Trigonella foenum), Zīra (Cuminum cyminum), Panbadana (Gossypium arborenum), Kalonjī (Nigella sativa) etc. from Unani classical texts are proven Pharmacologically and clinically for their galactogogue activity. In order to prove their efficacy and safety, further randomized clinical trials in larger sample should be conducted.

\section{AUTHOR CONTRIBUTION}

Sofia had made efforts for drafting article, data collection, data analysis, writing manuscript and critical revision of the article for the preparation of the manuscript.

\section{REFERENCES}

[1]. M. Gupta and B. Shaw, "A Double-Blind Randomized Clinical Trial for Evaluation of Galactogogue Activity of Asparagus racemosus Willd”, Iran J Pharm Res Winter, Vol. 10, Issue. 1, pp. 167-172, 2011.

[2]. R.A. Lawrence, R.M. Lawrence, "Breastfeeding: A guide for the medical profession”, St. Louis, MO: Mosby, $5^{\text {th }}$ ed., 1999.

[3]. C. Hillervik-Lindquist, Y. Hofvander, S. Sjolin, "Studies on perceived breast milk insufficiency. III. Consequences for breast milk consumption and growth", Acta Paediatr Scand, Vol. 80, Issue. 3, pp. 297-303, 1991.

[4]. N. Mohrbacher, J. Stock, "The breastfeeding answer book", Schaumburg, IL: La Leche League International, $3^{\text {rd }}$ revised edition, 2003.

[5]. A. Montgomery, N. Wight, "Use of Galactagogues in Initiating or Augmenting Maternal Milk Supply", The Academy of Breastfeeding Medicine Protocol Committee, 2004.

[6]. A.A. Zuppa, C. Sindico, Orichi et al, "Safety and efficacy of galactogogues: substances that induce, maintain and increase breast milk production", Journal of Pharmacy and Pharmaceutical Sciences, Vol. 13, Issue. 2, pp. 162-174, 2010.

[7]. I. Sina, “Al Qanoon Fil Tib (Urdu trans. by Kantoori GH)”, Vol II, Idara Kitabul Shifa, New Delhi, pp. 367-369, 2007.

[8]. A. Khan, Al Akseer (Urdu trans. by Kabeeruddin)”, Idara Kitabul Shifa, New Delhi, pp. 827, 2011.

[9]. A. Arzani, "Tibbe Akbar”, Faisal publication, Deoband, pp. 362-364, 1890.

[10]. M. Arzani, "Mizan e Tib", Idara kitabul Shifa, New Delhi, pp.128, 2002.

[11]. A.M.Z. Razi, "Kitab al Hawi”, Central Council for Research in Unani Medicine, New Delhi, pp.156, 2001.

[12]. R. Tabri, "Firdaus al Hikmat”, Idara Kitabul Shifa, New Delhi, pp. 260, 2002.

[13]. I. Baiter, "Al Jamili Mufridat Al Adviyah", Vol 4, Shristhi Book Distributors, pp. 73-74, 2005.

[14]. M. Kabeeruddin, "Ilmul Advia Nafeesi”, Ejaz Publishing House, New Delhi, pp. 238-266, 2007.

[15]. I. Jurjani, “Tarjuma e Zakheerae Khawarzam Shahi (Urdu trans. By Khan AH), Vol II Idara Kitabul Shifa, New Delhi, pp. 216-217, 2010.

[16]. A. Khan, "Haziq", Madina Publishing Company, Karachi, Pakistan, pp. 77-78, 1983.

[17]. J.J. Evans, "Oxytocin in the human - regulation of derivations and destinations" European Journal of Endocrinology, Vol. 137, pp. 559$571,1997$.

[18]. A. Sultana, A. Begum, S. Sultana, K. Asma, "Usefulness of Polyherbal Unani Formulation for Cervical Ripening and Induction of Labour: A Uncontrolled Study”, Altern Integ Med 4, pp. 184, 2015.

[19]. K. Mohd, Kanzul Advia Mufredah", University Publication Unit, Aligarh, pp. 210, 393-395, 1985.

[20]. H.M. Kabeeruddin, "Makhzanul Mufradat Al Maroof Khawasul Advia”, Ejaz Publication House, New Delhi, pp. 97, 163, 250, 266, 281, 400, 2007.

[21]. F. Ahmad, M. Aslam, Q. Nizami, “Classification of Unani Drugs”, Fine Offset Works, Delhi, pp.171, 2005.

[22]. N.Ghani, "Khazainul Advia", Idara Kitabul Shifa, New Delhi, pp. 202, 208, 227, 293, 321, 336, 402, 509, 542, 553, 853, 1061, 1271, 1272, 2005.

[23]. M.A. Hakeem, “Bustan ul Mufradat”, Idara Kitabul Shifa, New Delhi, pp.81-102, 2002.

[24]. M. Shah, “The General Principles of Avicenna's Canon of Medicine”, Idara Kitabul Shifa, New Delhi, India, 2007. 